\title{
DIREKTIVA (EU) 2017/828 O IZMJENI DIREKTIVE 2007/36/EZ U POGLEDU POTICANJA DUGOROČNOG SUDJELOVANJA DIONIČARA I NJEZINA IMPLEMENTACIJA U HRVATSKO PRAVO DRUŠTAVA ${ }^{1}$
}

Sažetak: $\quad$ Izmjenama i dopunama Zakona o trgovačkim društvima iz travnja 2019. godine usklađuju se njegove odredbe s odredbama Direktive (EU) 2017/828 o izmjeni Direktive 2007/36/EZ u pogledu poticanja dugoročnog sudjelovanja dioničara. Time se uvode novi regulatorni zahtjevi za uvrštena dionička društva radipoticanja dioničara sudjelovati u radu glavnih skupština kada za njih dionice pohranjuju i prava iz njih ostvaruju posrednici. Uvodi se transparentnost institucionalnih ulagača, upravitelja imovinom i savjetnika pri glasovanju o njihovoj politici sudjelovanja, dogovorima i pružanju usluga na glavnim skupštinama društava. $U$ određivanje politike primitaka članovima uprave, odnosno izvršnim direktorima tih društava uključuju se dioničari te se propisuje obveza izrade godišnjeg izvješća o primitcima članova upravnih, odnosno nadzornih tijela te izvršnih direktora. Poslove društva s povezanim osobama mora prethodno odobriti nadzorni, odnosno upravni odbor društva te se oni objavljuju na mrežnim stranicama društva.

Ključne riječi: $\quad$ Direktiva (EU) 2017/828, Zakon o trgovačkim društvima, uvrštena dionička društva, korporativno upravljanje, Republika Hrvatska

\footnotetext{
Dr. sc. Dionis Jurić, redoviti profesor, Pravni fakultet Sveučilišta u Rijeci, Hahlić 6, 51000 Rijeka, Republika Hrvatska. Adresa e-pošte: djuric@pravri.hr. ORCID: http://orcid.org/0000-0001-7725-7531.

1 Ovaj je rad izrađen uz potporu projekta Sveučilišta u Rijeci "Pravni aspekti restrukturiranja trgovačkih društava i tranzicija prema novoj kulturi korporativnog upravljanja".
} 


\section{UVOD}

Uvrštenje dionica dioničkih društava na uređena tržišta kapitala i njihova složena dioničarska struktura uvjetuje pojavu niza problema koji otežavaju kvalitetno korporativno upravljanje društvima. Pritom se osobito postavlja pitanje odnosa dioničara i društva te poticanja dioničara aktivno sudjelovati u radu njegove glavne skupštine, ali i osigurati da direktori društva vode računa o dugoročnoj uspješnosti i održivosti poslovanja pri vođenju poslova. Na razini Europske unije (dalje: EU) dodatnu dimenziju tom problemu daje pojava prekograničnog dioničarstva. Stoga je Europska komisija 2003. godine u svojem akcijskom planu predvidjela donošenje direktive koja će urediti ostvarivanje određenih prava dioničara u uvrštenim dioničkim društvima, a 11. srpnja 2007. godine donesena je Direktiva 2007/36/EZ Europskog parlamenta i Vijeća o ostvarenju određenih prava dioničara u dioničkim društvima uvrštenim na uređeno tržište (dalje: Direktiva 2007/36/EZ). ${ }^{2}$ Ta je Direktiva implementirana u hrvatsko pravo izmjenama i dopunama Zakona o trgovačkim društvima iz 2009. godine. ${ }^{3}$

Tijekom financijske krize i globalne recesije koje su trajale u razdoblju od 2007. do 2014. godine uočeno je da su direktori uvrštenih dioničkih društava prekomjerno preuzimali kratkoročne rizike pri vođenju poslova. Pritom se dioničari društava nisu u dovoljnoj mjeri angažirali u donošenju odluka na glavnim skupštinama, a uočene su i zapreke za njihovu bolju uključenost u rad skupština. Društva često nemaju informacija tko su krajnji ulagači kada je riječ o onim dionicama koje drže posrednici koji ostvaruju članska prava za dioničare. Kao dioničari društava pojavljuju se institucionalni ulagači te upravitelji imovinom koji su usmjereni na kratkoročne povrate svojih ulaganja te nedovoljno prate tijek poslovanja društava. To otežava ostvarenje kvalitetnog korporativnog upravljanja te usmjerenost poslovodstva k dugoročnoj uspješnosti i održivosti poslovanja društava. Stoga je bila potrebna daljnja zakonodavna intervencija tijela EU-a, što je urodilo donošenjem Direktive (EU) 2017/828 o izmjeni Direktive 2007/36/EZ u pogledu poticanja dugoročnog sudjelovanja dioničara 17. svibnja 2017. godine (dalje: Direktiva (EU) 2017/828). ${ }^{4}$

2 Čulinović-Herc, E.; Jurić, D., Prekogranični aspekti prava glasa - otvorena pitanja u europskom i hrvatskom pravu, Prekogranična i regionalna suradnja - zbornik radova s međunarodnog znanstvenog skupa, Pravni fakultet Sveučilišta u Rijeci, Rijeka, 2007., str. 219.-224., Kocbek, M., Revizija direktive o pravicah delničarjev - Direktiva (EU) 2017/828 Evropskega parlamenta in Sveta z dne 17 maja 2017 o spremembi Direktive 2007/36/ES glede spodbujanja dolgoročnega sodelovanja delničarjev, Podjetje in delo, god. XLIV, br. 2, 2018., str. 364.

3 Čulinović-Herc, E.; Hasić, T., Sudjelovanje dioničara u radu glavne skupštine dioničkog društva prema noveli Zakona o trgovačkim društvima, Zbornik Pravnog fakulteta Sveučilišta u Rijeci, god. 32, br. 1, 2011., str. 31.-32. i 36.-37. Direktiva 2007/36/EZ uredila je sljedeće institute i prava dioničara povezana s glavnom skupštinom: a) jednako postupanje s dioničarima u svezi sa skupštinom b) informacije koje se dostavljaju dioničarima prije održavanja skupštine c) pravo na dopunu dnevnog reda skupštine i davanje prijedloga odluka d) zahtjeve za sudjelovanje i glasovanja dioničara na skupštini e) sudjelovanje dioničara na skupštini uz pomoć elektroničkih sredstava f) pravo na postavljanje pitanja g) glasovanje preko punomoćnika h) formalnosti o imenovanju punomoćnika i urednom obavješćivanju i) glasovanje preko pošte j) uklanjanje određenih zapreka za učinkovito ostvarivanje prava glasa te k) rezultate glasovanja. Vidi u Kocbek, M., op. cit. u bilj. 1, str. 364.-365.

4 Direktiva (EU) 2017/828 Europskog parlamenta i Vijeća od 17. svibnja 2017. godine o izmjeni Direktive 2007/36/EZ u pogledu poticanja dugoročnog sudjelovanja dioničara (tekst značajan za EGP), Službeni list EU, L 132/1 (20. svibnja 2017.). 


\section{DIREKTIVA (EU) 2017/828 O IZMJENI DIREKTIVE 2007/36/ EZ U POGLEDU POTICANJA DUGOROČNOG SUDJELOVANJA DIONIČARA}

\subsection{DONOŠENJE, CILJEVI I SADRŽAJ DIREKTIVE (EU) 2017/828}

Analizirajući korporativno upravljanje u uvrštenim dioničkim društvima, Europska je komisija 12. prosinca 2012. godine u svom izvješću pod naslovom "Akcijski plan: europsko pravo trgovačkih društava i korporativno upravljanje - moderni pravni okvir za angažiranije dioničare i održiva trgovačka društva" predvidjela niz mjera u području korporativnog upravljanja, a osobito radi poticanja dugoročnog sudjelovanja dioničara u radu glavnih skupština i jačanja transparentnosti između društava i ulagača. ${ }^{5}$ Radi toga je 9. travnja 2014. godine izradila prijedlog izmjene Direktive 2007/36/EZ. ${ }^{6}$ Direktiva (EU) 2017/828 donesena je 17. svibnja 2017. godine te je države članice EU-a moraju implementirati u svoja nacionalna prava do 10. lipnja 2019. godine. Europska je komisija 3. rujna 2018. godine donijela i Provedbenu uredbu (EU) 2018/1212 o utvrdivanju minimalnih zahtjeva za provedbu odredbi Direktive 2007/36/EZ Europskog parlamenta i Vijeća u pogledu utvrđivanja identiteta dioničara, prijenosa informacija i olakšavanja ostvarivanja prava dioničara (dalje: Provedbena uredba (EU) 2018/1212). ${ }^{7}$ Provedbena je uredba u cijelosti obvezujuća te se neposredno primjenjuje u državama članicama EU-a, a cilj joj je osigurati ujednačenu primjenu odredbi Direktive (EU) 2017/828. ${ }^{8}$

Glavni je cilj Direktive (EU) 2017/828 ostvariti dugoročnu održivost dioničkih društava u EU-u, unaprijediti investicijsku klimu i ojačati prekogranično glasovanje dioničara te poboljšati učinkovitost lanaca kapitalnih ulaganja. Pojedinačni su ciljevi: a) povećati razinu i kvalitetu sudjelovanja ulagača u društvima u koja ulažu svoju imovinu b) ostvariti bolju povezanost primitaka direktora i uspješnosti poslovanja društava c) poboljšati transparentnost i nadzor dioničara nad poslovima društva s povezanim osobama d) osigurati pouzdano i kvalitetno pružanje usluga savjetnika za glasovanje institucionalnim ulagačima i upraviteljima imovinom te e) omogućiti prekogranično posredovanje informacija unutar ulagačkog lanca radi ostva-

$5 \quad$ Alineja 3. Direktive (EU) 2017/828.

6 Izradi prijedloga izmjene Direktive 2007/36/EZ prethodila su brojna javna savjetovanja sa zainteresiranim dionicima o korporativnom upravljanju u uvrštenim dioničkim društvima. Europska je komisija na temelju toga utvrdila glavne probleme u korporativnom upravljanju uvrštenim dioničkim društvima te je odredila ciljeve koje treba postići izmjenom Direktive 2007/36/ EZ. Vidi u Kocbek, M., op. cit. u bilj. 1, str. 366.-367.

7 Provedbena uredba Komisije (EU) 2018/1212 od 3. rujna 2018. o utvrđivanju minimalnih zahtjeva za provedbu odredbi Direktive 2007/36/EZ Europskog parlamenta i Vijeća u pogledu utvrđivanja identiteta dioničara, prijenosa informacija i olakšavanja ostvarivanja prava dioničara, Službeni list EU, L 223/1 (4. rujna 2018.).

8 Provedbena uredba (EU) 2018/1212 uređuje: a) standardizirane oblike, interoperabilnost i jezik b) zahtjev za otkrivanje informacija o identitetu dioničara i odgovor na taj zahtjev c) prijenos obavijesti o sazivanju glavne skupštine d) potvrdu ovlasti na ostvarivanje prava dioničara na glavnoj skupštini e) obavijest dioničara o sudjelovanju na glavnoj skupštini f) oblik potvrde o primitku glasova te bilježenju i brojanju glasova g) prijenos informacija o korporativnim događajima koji nisu glavne skupštine h) rokove koje moraju poštovati izdavatelji i posrednici pri korporativnim događajima i postupcima za utvrđivanje identiteta dioničara te h) minimalne sigurnosne zahtjeve. 
rivanja dioničarskih prava, a osobito uz pomoć identifikacije dioničara (krajnjih ulagača) od strane društva. ${ }^{9}$

Sukladno postavljenim ciljevima Direktiva (EU) 2017/828 mijenja odredbe Direktive 2007/36/EZ, odnosno dopunjuje ju novim odredbama radi poticanja dugoročnog sudjelovanja dioničara u glavnim skupštinama dioničkih društava koja su uvrstila svoje dionice na uređena tržišta kapitala: a) identifikacija dioničara, prijenos informacija i olakšanje ostvarivanja prava dioničara (poglavlje 1 A, članci 3.a-3.f) b) transparentnost institucionalnih ulagača, upravitelja imovinom i savjetnika pri glasovanju (poglavlje 1 B, članci 3.g.-3.k) c) politika primitaka direktora i prava dioničara te dostupnost informacija (članci 9.a-9.b) te d) transparentnost i odobrenje poslova društva s povezanim osobama (čl. 9.c). Budući da države članice EU-a na različite načine uređuju neke od ovih problema u svojim nacionalnim pravima, implementacija Direktive (EU) 2017/828 osigurat će ujednačenje pravnih rješenja, ali uvesti i neka nova koja doprinose ostvarenju postavljenih ciljeva.

\section{IMPLEMENTACIJA DIREKTIVE (EU) 2017/828 U HRVATSKOM PRAVU DRUŠTAVA}

Hrvatski je Zakon o trgovačkim društvima (dalje: ZTD) usklađen s odredbama Direktive (EU) 2017/828 Zakonom o izmjenama i dopunama ZTD-a (dalje: ZID ZTD) iz travnja 2019. godine. ${ }^{10}$ ZID ZTD dopunjuje postojeće odredbe o vođenju registra dionica radi osiguravanja izravne komunikacije društva s dioničarima. Uređuju se pretpostavke za upis posrednika u registar dionica te se uvodi njihova obveza dostaviti društvu informacije o identitetu krajnjih ulagača. Uređuje se prijenos propisanih informacija između društva i dioničara te posrednika elektroničkim putem. Time se krajnjim ulagačima olakšava osobno ostvarivati prava na skupštini, ako tako odluče. Uvode se nove odredbe o obvezi institucionalnih ulagača, upravitelja imovinom i savjetnika pri glasovanju objavljivati na svojim mrežnim stranicama politike sudjelovanja, dogovore i podatke o pružanju usluga krajnjim korisnicima. To omogućava bolju obaviještenost te nadzor krajnjih korisnika nad njihovim radom. Uvodi se obveza izrade politike primitaka za direktore te provedba revizije primitaka članova nadzornih tijela društava, kao i izrada godišnjeg izvješća o primitcima tih osoba. Glavna skupština odobrava politiku primitaka i godišnje izvješće o primitcima, čime se u odlučivanje o tim pitanjima uključuju dioničari. Nove odredbe uređuju obvezu direktora pribaviti suglasnost nadzornog tijela za sklapanje poslova s osobama koje su povezane s društvom te ih objaviti na mrežnim stranicama društva. Time se štiti društvo i njegovi manjinski dioničari od zadiranja u imovinu društva. ${ }^{11}$

$9 \quad$ Ibid., str. 366.

10 Zakon o izmjenama i dopunama Zakona o trgovačkim društvima, Narodne novine, broj 40/2019. Postupak usklađivanja odredbi ZTD-a otpočeo je 30. studenog 2018. godine objavom Nacrta prijedloga ZID ZTD-a na mrežnoj stranici e-Savjetovanje. Savjetovanje je bilo otvoreno do 30. prosinca 2018. godine i nakon pristizanja primjedbi zainteresiranih strana objavljeno je izvješće o savjetovanju 21. siječnja 2019. godine. Vlada RH je 4. travnja 2019. godine uputila Konačni prijedlog ZID ZTD-a na raspravu u Hrvatskom saboru te je on jednoglasno izglasan 11. travnja 2019. godine.

11 Vlada RH, Konačni prijedlog zakona o izmjenama i dopunama Zakona o trgovačkim društvima, Zagreb, travanj 2019., URL=https:// sabor.hr/sites/default/files/uploads/sabor/2019-04-04/164502/PZE-599.pdf. Pristupljeno 9. travnja 2019., str. 56.-58. 


\subsection{IDENTIFIKACIJA DIONIČARA, PRIJENOS INFORMACIJA I OLAKŠANJE OSTVARIVANJA PRAVA DIONIČARA}

U praksi uvrštenih dioničkih društava uočena je pojava držanja dionica preko složenih lanaca posrednika. ${ }^{12} \mathrm{U}$ ulozi posrednika pojavljuju se kreditne institucije i investicijska društva koja pružaju usluge pohrane i skrbništva nad vrijednosnim papirima, odnosno upravljanja portfeljem vrijednosnih papira svojih klijenata. ${ }^{13}$ Pravni odnosi između posrednika i dioničara zasnivaju se sklapanjem ugovora o polaganju vrijednosnih papira i ugovora o skrbništvu nad vrijednosnim papirima, odnosno ugovora o upravljanju portfeljem vrijednosnih papira ili ugovora o upravljanju financijskom imovinom. Prednosti su tih ugovora što dioničari povjeravaju dionice na čuvanje posrednicima te ih ovlašćuju na poduzimanje radnji kojima se ostvaruju prava iz njih, raspolaganje tim dionicama te stjecanje drugih vrijednosnih papira za račun dioničara. Posrednici prate korporativne događaje i poslovanje društva te postupaju po nalozima koje im daju dioničari. Posrednici kao profesionalci pružaju te usluge, a dioničare oslobađaju brige o ostvarivanju prava i upravljanju vrijednosnim papirima koji su kod njih pohranjeni. ${ }^{14}$ Nedostatak je takvog držanja dionica pasivnost krajnjih ulagača u nadzoru nad radom posrednika te davanju naloga o tomu kako ostvarivati prava iz dionica u pohrani. Postavlja se i pitanje kvalitete informiranosti krajnjih ulagača o poslovanju društva te sazivanju i tijeku glavne skupštine te korporativnim događajima u društvu. Njihova bolja informiranost im omogućava odlučiti hoće li svoja prava na skupštini ostvarivati osobno, umjesto korištenja usluga posrednika. ${ }^{15}$ Stoga je potrebno osigurati društvu utvrđivanje identiteta krajnjih ulagača radi izravne komunikacije, čime se olakšava ostvarivanje njihovih prava na skupštini. To je od osobitog značaja pri pojavi prekograničnog dioničarstva i korištenju elektroničkih sredstava za ostvarivanje prava dioničara. Posrednici bi trebali biti obvezni društvu, na njegov zahtjev, dostaviti informacije o identitetu krajnjih ulagača. ${ }^{16}$

Obveza je društva voditi registar dionica u koji se upisuju dionice koje glase na ime te podatci o imateljima tih dionica (čl. 226. st. 1. ZTD-a). Svrha je njegova vođenja utvrđivanje tko je imatelj dionica te tko može ostvarivati članska prava u društvu. ZID ZTD u čl. 32. uređuje izmjene čl. 226. st. 1.-3. ZTD-a radi usklađivanja s odredbama Direktive (EU) 2017/828. ${ }^{17}$ Radi uspostave izravne komunikacije s dioničarima, ZID ZTD mijenja čl. 226. st. 1. ZTD-a te određuje koji se podatci upisuju u registar dionica o imateljima dionica te dionicama. ${ }^{18}$ Radi

12 European Commission, Commission staff working document: impact assessment accompanying the document Proposal for a Directive of the European Parliament and of the Council on amending Directive 2007/36/EC as regards the encouragement of long-term shareholder engagement and Directive 2013/34/EU as regards certain elements of the corporate governance statement and Commission Recommendation on the quality of corporate governance reporting ('comply or explain'), SWD(2014) 127 final, Bruxelless, travanj 2014., URL=https://eur-lex.europa.eu/legal-content/EN/TXT/?uri=CELEX:52014SC0127. Pristupljeno 29. svibnja 2019., str. 34.

13 Belanić, L.; Bilić, A.; Gorenc, V.; Kunštek, E.; Markovinović, H.; Mihalina, E.; Mihelčić, G.; Miladin, P.; Mišćenić, E.; Perkušić, M.; Petrić, S.; Slakoper, Z.; Šrajfer, J.; Tepeš, N.; Tot, I.; Vukmir, B., Bankovni i financijski ugovori, Narodne novine, Zagreb, 2017., str. 935.-940. i 957.-964.

15 European Commission, op. cit. u bilj. 12, str. 34.-37.

16 Alineja 4. Direktive (EU) 2017/828.

17 Članak 32. ZID ZTD-a stupa na snagu 1. siječnja 2021. godine (čl. 96. ZID ZTD-a).

18 U registar dionica upisuju se dionice društva te njihov broj i nominalni iznos ako je društvo izdalo dionice s nominalnim iznosom, a ako je izdalo dionice bez nominalnog iznosa njihov broj te imena i prezimena, prebivališta, odnosno tvrtke i sjedišta te osobni 
toga dodatno traži upis poštanskih adresa i adresa elektroničke pošte imatelja dionica. Oni su obvezni te podatke dostavljati društvu te snose rizik neprijavljivanja eventualnih promjena tih adresa.

Poseban problem predstavljaju dionice koje su dane u pohranu i skrbništvo posrednicima (kreditne institucije, investicijska društva, središnji depozitoriji). Ovisno o vrsti skrbničkog računa na kojem se vode te dionice ovisi i mogućnost društva utvrditi tko je krajnji ulagač u društvo. To osobito dolazi do izražaja ako je društvo izdalo dionice kao vrijednosne papire u nematerijaliziranom obliku koje se vode u središnjem depozitoriju. Skrbnički račun može biti na ime, pod zaporkom i zbirni račun. Zakon o tržištu kapitala (dalje: ZTK) ${ }^{19}$ dopušta da taj račun glasi na posrednika koji pruža usluge pohrane i skrbništva, odnosno upravljanja portfeljem vrijednosnih papira. Kod skrbničkog računa na ime račun otvara posrednik, ali je identitet ulagača poznat. Kod skrbničkog računa pod zaporkom ili zbirnog skrbničkog računa taj račun otvara posrednik, a jedino on zna tko su ulagači. U tom se slučaju skrbnički račun vodi na ime posrednika, ali je imatelj tih dionica osoba koja ih je povjerila na skrbništvo posrednicima. ${ }^{20}$ Kada je riječ o upisu imatelja dionica u registar dionica, ZID ZTD mijenja čl. 226. st. 1. ZTD-a te određuje da se statutom može odrediti pod kojim je pretpostavkama dopušteno upisati dionice $u$ registru dionica na svoje ime, a kada one pripadaju nekom drugom. ${ }^{21}$ Njime se može odrediti i obveza posrednika izvijestiti društvo o identitetu krajnjih ulagača (stvarnih dioničara). Ako su dionice upisane u registru dionica na domaći, inozemni ili investicijski fond iz EU-a, a imatelji njihovih udjela ili dionica nisu isključivo institucionalni ulagači, dioničarima se smatraju ti fondovi neovisno o tomu što su ulagači imatelji tih dionica. Ako investicijski fond nema pravnu osobnost, smatra se da su to dionice društva za upravljanje investicijskim fondom.

ZID ZTD mijenja čl. 226. st. 2. ZTD-a te određuje da se u odnosu prema društvu priznaju prava i obveze iz dionice samo onome tko je upisan u registru dionica. ${ }^{22}$ Ako je društvo izdalo dionice kao vrijednosne papire u nematerijaliziranom obliku, mjerodavno je stanje na računu dioničara koji za dionice društva vodi ovlaštena pravna osoba u središnjem depozitoriju. ${ }^{23}$ Za vođenje i točnost podataka u registru dionica odgovara uprava, odnosno izvršni direktori društva, s time da njegovo vođenje mogu povjeriti i trećim osobama izvan društva. ${ }^{24} \mathrm{U}$ slučaju da osoba na koju su dionice upisane u registar dionica sukladno statutu (posrednik) prekrši svoju obvezu otkriti kome pripadaju dionice koje su na nju upisane, neće moći ostvarivati pravo glasa iz tih dionica. Dionice ne daju pravo glasa ni nakon proteka roka za davanje obavijesti o identitetu dioničara uz prijetnju gubitka prava glasa na zahtjev društva sve dok se društvu

identifikacijski brojevi imatelja dionica. U njega se upisuju i privremenice te njihovi imatelji, a preporučuje se i upis dionica koje glase na donositelja (upisuje se činjenica da su izdane i brojevi koje nose), ali bez podatka o imateljima takvih dionica. trgovačkih društava u doba recesije, Pravni fakultet Sveučilišta u Rijeci, Rijeka, 2011., str. 359.-362., Belanić, L. et al., op. cit. u bilj. 13, str. 989.-991.

21 Statutom se može odrediti da to može biti samo neka točno određena osoba ili samo neke točno određene osobe (investicijski fondovi, kreditne i financijske institucije, udruge dioničara).

22 Riječ je o dionicama koje glase na ime, bez obzira na to jesu li za njih izdane ili nisu izdane isprave o dionicama. Za njih je vođenje registra dionica obvezatno.

23 Vođenje registra dionica u tomu je slučaju fakultativno. 
ne dadu te obavijesti. Time se propisuju sankcije ako posrednici ne postupe u skladu sa svojom obvezom obavješćivanja društva o identitetu ulagača za koje drže dionice.

Kada se dionica prenosi, brisanje ranijeg dioničara i upis novoga provodi se u registru na temelju zahtjeva kojem se mora priložiti dokaz o tomu da je ona prenesena. ${ }^{25}$ Posrednici moraju uz naknadu troškova dati društvu sve potrebne podatke za vođenje registra dionica. ${ }^{26}$ Svatko tko je upisan u registru dionica mora bez odgode izvijestiti društvo, na njegov zahtjev, o tomu jesu li to njegove dionice (čl. 226. st. 3. ZTD-a). ${ }^{27}$

ZID ZTD u čl. 51. određuje obvezu društva informirati dioničara o sazivanju glavne skupštine i korporativnim događajima u društvu, kao i obvezu posrednika informirati društvo o identitetu stvarnog dioničara te informacijama koje je dioničar dao posredniku u svezi s ostvarivanjem prava iz dionica koje su u skrbništvu (novi članci 297.a-297.f. ZTD-a). ${ }^{28}$ Time se olakšava ostvarivanje prava dioničara na skupštini. Ako društvo ne prenese informacije o sazivanju skupštine i određenim korporativnim događajima ${ }^{29}$ izravno dioničarima, ono mora te informacije elektronički proslijediti posrednicima radi njihova prenošenja dioničarima (čl. 297.a st. 1. ZTD-a). Ako su te informacije dostupne na mrežnim stranicama društva, dovoljno je posrednicima dati podatak o tim stranicama. U slučaju postojanja lanca posrednika (tzv. višestupnjevito skrbništvo), svaki pojedini posrednik u lancu mora bez odgode prenijeti navedene informacije, koje je primio od drugog posrednika ili društva, posredniku u lancu koji neposredno slijedi, osim ako zna da je društvo već poslalo te informacije posredniku koji neposredno slijedi (čl. 297.a st. 3. ZTD-a). ${ }^{30}$ Posrednik mora primljene informacije prenijeti dioničaru bez odgode elektroničkim putem, a ako su one dostupne na mrežnim stranicama društva, dovoljno je uputiti dioničare na te stranice (čl. 297.b st. 1. ZTD-a). ${ }^{31}$

$\mathrm{S}$ druge strane, posrednik mora prenijeti informacije koje mu je dao dioničar o ostvarivanju njegovih prava iz dionica (npr. upute o tomu kako glasovati, odobrenje danog glasa) bez odgode izravno društvu ili posredniku u lancu, sve dok one ne stignu društvu (čl. 297.c. st. 1. ZTD-a). Obveza je posrednika bez odgode dostaviti dioničaru na njegov zahtjev pisanu potvrdu o njegovim dionicama ili ju proslijediti društvu (čl. 297.c st. 2. ZTD-a). Njome on dokazuje svoje svojstvo dioničara pri sazivanju glavne skupštine. Time se olakšava dioničaru osobno sudjelovati i glasovati na skupštini umjesto posrednika, ako dioničar tako odluči.

25 U registar dionica upisuju se i sve ostale promjene podataka koje se odnose na samu dionicu, a upisuju se u registar dionica.

26 Barbić, J., op. cit. u bilj. 24, str. 495. i 496.-497.

27 Ako je posrednik samo privremeno upisan u registar dionica radi prijenosa dionica, nema obvezu obavještavati društvo o identitetu dioničara.

28 Članak 51. ZID ZTD-a stupa na snagu 1. siječnja 2021. godine (čl. 96. ZID ZTD-a).

29 To su sljedeći korporativni događaji: o pravima na zamjenu zamjenjivih obveznica za dionice, prvenstvu pri upisu novih dionica, naplati, primjerice, u povodu smanjenja temeljnog kapitala povlačenjem dionica, upisu novih dionica pri povećanju temeljnog kapitala te izboru pri isplati dividende.

30 Navedene odredbe primjenjuju su na sva dionička društva sa sjedištem u RH, koja su uvrstila svoje dionice na uređeno tržište radi trgovanja u RH ili na uređeno tržište u nekoj drugoj državi članici EU-a. Posrednici mogu imati sjedište u RH, drugoj državi članici EU-a, u drugoj državi Sporazuma o Europskom gospodarskom prostoru ili nekoj trećoj državi.

31 To vrijedi i za informacije društva čije su dionice uvrštene na uređeno tržište radi trgovanja sa sjedištem u drugoj državi članici EU-a (čl. 279.b st. 2. ZTD-a). 
Uvrštena dionička društva smiju uvijek zahtijevati od posrednika informacije o identitetu dioničara čije dionice drže u pohrani (čl. 297.d st. 1. ZTD-a). ${ }^{32}$ Ako je riječ o neuvrštenom dioničkom društvu, tada se njegovim statutom može propisati pravo društva tražiti od posrednika informacije o identitetu dioničara (čl. 297.d st. 6. ZTD-a). ${ }^{33}$

Društvo ima obvezu podmirivati nužne troškove posrednika nastale zbog primjene odredbi ZTD-a o informiranju dioničara i društva, a posrednici moraju objaviti naknade tih troškova te ih zasebno priopćiti društvu i dioničaru za kojeg obavljaju usluge pohrane, skrbništva ili upravljanja portfeljem vrijednosnih papira (čl. 297.f ZTD-a).

Sukladno čl. 41. ZID ZTD-a, koji mijenja čl. 274. st. 1. i 2. ZTD-a, ako se pravo glasa na glavnoj skupštini ostvaruje elektroničkom komunikacijom, društvo mora osobi koja je dala glas elektronički potvrditi primitak takvog glasa. Članak 48. ZID ZTD-a dodaje st. 6. u čl. 285. ZTD-a koji određuje da svaki dioničar ima pravo zahtijevati od društva potvrdu o tomu je li i kako dan njegov glas u roku od mjesec dana nakon održane skupštine, a društvo mu mora bez odgode izdati tu potvrdu. ${ }^{34}$

\subsection{TRANSPARENTNOST INSTITUCIONALNIH ULAGAČA, UPRAVITELJA IMOVINOM I SAVJETNIKA PRI GLASOVANJU}

U uvrštenim dioničkim društvima često se kao dioničari pojavljuju institucionalni ulagači i upravitelji imovinom koji mogu utjecati na kvalitetu korporativnog upravljanja društvima te na njihovu poslovnu strategiju i ostvarivanje dugoročnih rezultata. Praksa je pokazala da ti ulagači ne sudjeluju u dovoljnoj mjeri u radu glavnih skupština te su usmjereni na kratkoročne povrate svojih ulaganja. ${ }^{35}$ Stoga je potrebno uspostaviti preglednost njihovih strategija ulaganja, politike sudjelovanja u društvima u koja ulažu imovinu koju su prikupili od krajnjih korisnika i njezine provedbe. To omogućava bolju informiranost njihovih krajnjih korisnika (osiguranika, članova mirovinskih fondova, ulagača u investicijske fondove) te kvalitetniji nadzor nad radom institucionalnih ulagača i upravitelja imovinom. ${ }^{36}$ Pri ostvarivanju prava glasa na skupštinama uvrštenih dioničkih društava investicijski se ulagači i upravitelji imovinom koriste uslugama savjetnika pri glasovanju koji provode analize, istraživanja, savjetuju

32 Društvo može tražiti propisane osobne podatke o dioničaru (ulagaču), njegovoj poštanskoj i elektroničkoj adresi te njegovim dionicama (broj i rod dionica te datum od kojeg se dionice drže) (čl. 297.d st. 2. ZTD-a). U slučaju postojanja lanca posrednika, obveza je posrednika u lancu prosljeđivati zahtjev društva za dostavom tih informacija do posrednika koji ima podatke o dioničaru (krajnjem ulagaču), kao i njegova obveza dostaviti tražene informacije posrednicima u lancu sve dok one ne stignu posredniku kojem je društvo postavilo zahtjev za priopćenje informacija o identitetu dioničara (čl. 297.d. st. 3. i 4. ZTD-a). njihovih prava i suradnje s dioničarima. Ako društvo ili posrednici saznaju da neka osoba više nije dioničar društva, smiju pohranjivati njegove osobne podatke još najdulje 12 mjeseci, a dopušteno je i dulje pohranjivati te podatke ako je to potrebno za vođenje određenih pravnih postupaka. Svaka osoba ima pravo tražiti i ispravak tih informacija ako su one nepotpune ili pogrešne (čl. 297.e ZTD-a). 
te daju preporuke kako glasovati na skupštinama. ${ }^{37}$ Stoga je potrebno uspostaviti preglednost pružanja usluga savjetnika pri glasovanju. ${ }^{38}$

ZID ZTD u čl. 49. dopunjuje odredbe ZTD-a uvođenjem novih članaka 291.a-291.d koji uređuju transparentnost institucionalnih ulagača, upravitelja imovinom i savjetnika pri glasovanju. Pod institucionalnim se ulagačima podrazumijevaju: a) osiguravajuća društva i društva za reosiguranje koja obavljaju djelatnosti životnog osiguranja, odnosno reosiguranja obveza životnog osiguranja te b) mirovinska društva, obvezni i dobrovoljni mirovinski fondovi te institucije za strukovno mirovinsko osiguranje. Pod upraviteljima imovinom podrazumijevaju se: a) kreditne institucije i investicijska društva koja pružaju investicijske usluge i aktivnosti b) društva za upravljanje UCITS fondovima i upravitelji alternativnih investicijskih fondova (čl. 291.a st. 1. ZTD-a).

Institucionalni ulagači i upravitelji imovinom javno objavljuju politiku sudjelovanja u društvima u koja su uložili imovinu prikupljenu od krajnjih korisnika na svojim mrežnim stranicama te se propisuju informacije koje ona mora sadržavati (čl. 291.b st. 1. ZTD-a). ${ }^{39}$ Oni moraju jedanput na godinu podnijeti izvješće o provedbi politike sudjelovanja (čl. 291.b st. 2. ZTD-a) ${ }^{40}$ te javno objaviti kako su glasovali na glavnim skupštinama, osim ako njihovi glasovi nisu bili bitni zbog sadržaja odluka o kojima se glasovalo ili zbog njihovog zanemarivo niskog udjela u temeljnom kapitalu društva (čl. 291.b st. 3. ZTD-a). Institucionalni ulagači i upravitelji imovine moraju ispuniti propisane zahtjeve ili objasniti zašto ih nisu ispunili (čl. 291.b st. 4. ZTD-a). Navedene informacije moraju biti besplatno dostupne na mrežnim stranicama institucionalnog ulagača i upravitelja imovine barem tri godine te se moraju najmanje jedanput na godinu obnoviti (čl. 291.b st. 5. ZTD-a). ${ }^{41}$

Srednjoročni do dugoročni pristup pri kreiranju strategije ulaganja institucionalnih ulagača i upravitelja imovinom doprinosi ostvarenju interesa njihovih krajnjih korisnika te kvalitetnijem korporativnom upravljanju društvima u koja ulažu. ${ }^{42}$ Stoga su institucionalni ulagači obvezni javno objaviti u kojoj su mjeri glavni elementi njihove strategije ulaganja u skladu s profilom i trajanjem njihovih obveza, te kako oni pridonose srednjoročnim do dugoročnim

37 Ta se praksa osobito javlja kod ulagača s visoko diverzificiranim portfeljima te inozemnim ulagačima.

38 Alineja 25. i 26. Direktive (EU) 2017/828.

39 U politici sudjelovanja moraju naznačiti kako: a) utječu na društva u portfelju b) koriste članska prava iz dionica za svoje strategije ulaganja c) nadgledaju bitne događaje društva u koje ulažu d) razmjenjuju stajališta s tijelima društva i drugim dionicima $u$ društvu e) ostvaruju članska prava iz dionica f) surađuju s drugim dioničarima te g) upravljaju sukobima interesa povezanima sa sudjelovanjem.

40 U njemu objašnjavaju kako općenito glasuju, kako su glasovali o značajnijim odlukama i jesu li koristili usluge savjetnika pri glasovanju.

41 Institucionalni ulagači mogu umjesto toga uputiti na mrežne stranice upravitelja imovine ako se na njima nalaze te informacije.

42 Institucionalni ulagači i upravitelji imovinom usredotočeni su na kratkoročne povrate svojih ulaganja (kupnja i prodaja dionica) te izbjegavaju dugoročno držanje dionica u društvima i ostvarivanje prava na njihovim glavnim skupštinama (dugoročna ulaganja). Oni ne posvećuju dovoljno pozornosti dugoročnoj uspješnosti poslovanja društava te donose odluke o ulaganjima na temelju kretanja cijena dionica i strukture indeksa tržišta kapitala (referentne vrijednosti). Uzrok je tomu neusklađenost njihovih interesa, ali i njihove potrebe za likvidnošću te prilike na tržištu kapitala. Institucionalni ulagači imaju dugoročne interese s obzirom na svoje obveze prema krajnjim korisnicima, a pri izboru i ocjeni rada upravitelja imovinom oslanjaju se na referentne vrijednosti koje su kratkoročnog karaktera. S druge strane, upravitelji imovinom brinu se o svojoj kratkoročnoj uspješnosti te uspješnosti poslovanja drugih upravitelja. Time se ne ostvaruje optimalan povrat ulaganja za krajnje korisnike. U odnosu na uvrštena dionička društva to slabi kvalitetu korporativnog upravljanja, povećava preuzimanje kratkoročnih rizika pri donošenju poslovnih odluka te dovodi do gubitka potencijala rasta njihovih financijskih pokazatelja. Vidi u European Commission, op. cit. u bilj. 12, str. 21.-25. 
kretanjima vrijednosti njihova portfelja (čl. 291.c st. 1. ZTD-a). Ako se koriste uslugama upravitelja imovinom, institucionalni ulagač mora javno objaviti podatke o dogovoru s upraviteljem imovine koji objašnjava kako upravitelj usklađuje svoju strategiju ulaganja i odluke o ulaganju s profilom i trajanjem obveza institucionalnog ulagača (čl. 291.c st. 2. ZTD-a).$^{43} \mathrm{Te}$ informacije institucionalni ulagač mora objaviti na svojim mrežnim stranicama te ih učiniti besplatno dostupnim na razdoblje od barem tri godine te ih mora obnoviti najmanje jedanput na godinu (čl. 291.c st. 3. ZTD-a). ${ }^{44}$ Upravitelj imovine koji je sklopio dogovor s institucionalnim ulagačem mora jedanput na godinu podnijeti izvješće institucionalnom ulagaču ili objaviti na svojim mrežnim stranicama javno dostupne informacije o usklađenosti njegove strategije ulaganja i njezine provedbe $s$ tim dogovorom te kako pridonosi srednjoročnim do dugoročnim kretanjima vrijednosti portfelja institucionalnog ulagača (čl. 291.c st. 4. ZTD-a).

Savjetnici pri glasovanju moraju jedanput na godinu dati izjavu o primjeni pravila nekog kodeksa ponašanja (primjena prema načelu "postupi ili objasni”) ili navesti da ih nisu primjenjivali te objasniti zašto su tako postupali (čl. 291.d st. 1. ZTD-a). Jedanput na godinu moraju sastaviti te objaviti izvješće o svojem radu (291.d st. 2. ZTD-a). ${ }^{45}$ Navedene informacije moraju biti javno i besplatno dostupne na mrežnim stranicama savjetnika pri glasovanju najmanje tri godine od dana objave te ih on mora obnoviti najmanje jedanput na godinu (čl. 291.d st. 3 . ZTD-a). Savjetnici pri glasovanju moraju bez odgode obavijestiti svoje klijente o sukobu interesa te protumjerama koje su poduzeli (čl. 291.d st. 4. ZTD-a).

\subsection{POLITIKA PRIMITAKA DIREKTORA I PRAVA DIONIČARA TE DOSTUPNOST INFORMACIJA}

Određivanje i provedba politike primitaka direktora uvrštenih dioničkih društava ${ }^{46}$ značajni su čimbenici kvalitetnog korporativnog upravljanja. Stoga strukturu i oblike primitaka direktora treba vezati uz ostvarenje poslovne strategije, dugoročne interese i održivost poslovanja društva. Budući da o tim pitanjima odlučuju nadzorna tijela društva, u oblikovanje politike primitaka i nadzor nad njezinom provedbom treba uključiti dioničare. Konačno, valja osigurati preglednost provedbe te politike izradom odgovarajućeg izvješća o primitcima. ${ }^{47}$ Tom se problematikom bavila i Europska komisija koja je tijekom 2000-ih donijela nekoliko preporuka o tim pitanjima. ${ }^{48}$ Neke su od tih preporuka usvojene i u hrvatskom Kodeksu korporativnog upravljanja iz 2011. godine koji se primjenjuje na društva čije su dionice uvrštene

43 Propisuju se i podatci koji trebaju biti sadržani u tomu izvješću ili se objašnjava zašto neki od tih podataka nije sadržan u njemu.

44 On može umjesto toga uputiti na mrežne stranice upravitelja imovine ako se na njima nalaze te informacije.

45 Propisuju se i podatci koji moraju biti sadržani u tomu izvješću.

46 Pod direktorima se podrazumijevaju članovi uprave i nadzornog odbora, odnosno izvršni direktori i članovi upravnog odbora društva.

47 Alineja 28.-41. Direktive (EU) 2017/828.

48 Tako je Europska komisija donijela Preporuku o primitcima direktora u uvrštenim dioničkim društvima iz 2004. godine, Preporuku o ulozi članova nadzornih odbora ili neizvršnih direktora u upravnim odborima uvrštenih dioničkih društva i o komisijama nadzornog/upravnog odbora iz 2005. godine, Preporuku o režimu primitaka direktora uvrštenih dioničkih društava iz 2009. godine te Preporuku o kvaliteti izvještavanja o korporativnom upravljanju iz 2014. godine. Preporuke Europske komisije našle su svoje mjesto u nacionalnim kodeksima korporativnog upravljanja, a neke i u propisima država članica EU-a. O sadržaju preporuka i njihovoj implementaciji u državama članicama vidi podrobnije u Jurić, D., Primanja za rad i objavljivanje podataka 
na uređeno tržište u RH. S obzirom na njegovu neobvezujuću narav, praksa ukazuje da društva često ne postupaju u skladu s preporukama Kodeksa. Odredbe Direktive (EU) 2017/828 o tomu doprinijet će ostvarenju obvezujućeg i usklađenog režima politike primitaka u uvrštenim dioničkim društvima na području EU-a.

Člankom 34. ZID ZTD-a uvodi se novi članak 247.a ZTD-a koji uređuje postupak izrade te sadržaj politike primitaka direktora uvrštenih dioničkih društava. ${ }^{49}$ Nadzorni, odnosno upravni odbor odlučuje o sustavu primitaka članova uprave, odnosno izvršnih direktora te se propisuje sadržaj politike primitaka (čl. 247.a st. 1. ZTD-a). ${ }^{50}$ Politiku primitaka članova uprave, odnosno izvršnih direktora utvrđuje nadzorni, odnosno upravni odbor surađujući s glavnom skupštinom, koja je odobrava. Nadzorni, odnosno upravni odbor smije privremeno odstupiti od politike primitaka ako to nužno zahtijeva dugoročna dobrobit društva, a politika je primitaka to predvidjela te se u njoj navodi u kojem se dijelu smije odstupiti od utvrđene politike primitaka i prema kojem postupku (čl. 247.a st. 2. ZTD-a). Politika primitaka predstavlja okvir unutar kojega nadzorni, odnosno upravni odbor društva odlučuje o individualnim primitcima pojedinih članova uprave, odnosno izvršnih direktora.

Člankom 40. ZID ZTD-a uvodi se novi članak 272.r ZTD-a koji uređuje obvezu izrade izvješća o primitcima. ${ }^{51}$ Uprava i nadzorni odbor, odnosno izvršni direktori i upravni odbor društva sastavljaju jedanput na godinu izvješće o svim primitcima koje je društvo ili neko drugo društvo u sastavu istoga koncerna isplatilo ili se obvezalo isplatiti svakom sadašnjem i bivšem članu uprave i nadzornog odbora, odnosno izvršnom direktoru i članu upravnog odbora tijekom posljednje poslovne godine. To izvješće sadrži ime i prezime navedenih osoba i podatke o isplatama primitaka, izmjenama tih primitaka, dodijeljenim dionicama ili opcijama za stjecanje dionica društva, zahtjevima za povrat varijabilnih primitaka, odstupanjima od odobrene politike primitaka te odobrenje glavne skupštine izvješća o primitcima za prošlu poslovnu godinu (čl. 272.r st. 1. ZTD-a). ${ }^{52}$

o primanjima za rad članova uprave i nadzornog odbora dioničkog društva, Financiranje, upravljanje i restrukturiranje trgovačkih društava u doba recesije, Pravni fakultet Sveučilišta u Rijeci, Rijeka, 2011., str. 120.-154.

49 Nadzorni, odnosno upravni odbori utvrđivat će politiku primitaka surađujući s glavnom skupštinom od 1. svibnja 2020. godine (čl. 93. ZID ZTD-a).

50 U politici primitaka naznačuju se: a) oblici i struktura primitaka (fiksni i varijabilni dio) b) kako primitci doprinose poslovnoj strategiji i dugoročnom razvoju društva c) mjerila za isplatu varijabilnih primitaka d) razdoblja odgode isplate dijela primitka i pravo društva na povrat varijabilnih primitaka e) uvjeti za dodjelu dionica društva i zabrana njihova otuđenja u određenom razdoblju f) menadžerski ugovor ili drugi odgovarajući ugovor s propisanim podatcima g) objašnjenje kako su se pri utvrđivanju primitaka uzimali u obzir uvjeti radničkih primitaka i uvjeti rada te objašnjenje koji je krug radnika bio uključen u donošenje politike primitaka h) postupak donošenja, provedbe i nadzora politike primitaka te uloga posebnih komisija nadzornog, odnosno upravnog odbora te i) podatci o eventualnim izmjenama politike primitaka, ako za prijašnju politiku primitaka glavna skupština ne da odobrenje.

51 Članak 40. ZID ZTD-a stupa na snagu 1. svibnja 2020. godine (čl. 96. ZID ZTD-a).

52 Izvješće o primitcima za svakog člana uprave, odnosno izvršnog direktora treba sadržavati podatke i o primitcima koje su mu isplatile ili obvezale isplatiti u poslovnoj godini treće osobe u svezi s poslovima koje je obavljao kao član uprave, odnosno izvršni direktor, primitcima koje se društvo obvezalo isplatiti članu uprave, odnosno izvršnom direktoru u slučaju prijevremenog ili redovitog prestanka njegove funkcije (otpremnina) te primitcima koje je društvo isplatilo ili se obvezalo isplatiti bivšem članu uprave, odnosno izvršnom direktoru, kojemu je funkcija prestala u prošloj poslovnoj godini (čl. 272.r st. 2. ZTD-a). Izvješće o primitcima ne smije sadržavati podatke koji se tiču obiteljskih prilika pojedinih članova uprave i nadzornog odbora, odnosno izvršnih direktora i članova upravnog odbora (čl. 272.r st. 5. ZTD-a). Ono ne treba sadržavati podatke koji, prema prosudbi razumnog gospodarstvenika, mogu nanijeti društvu štetu koja nije beznačajna (čl. 272.r st. 6. ZTD-a). 
Izvješće o primitcima mora ispitati revizor koji ispituje i godišnja financijska izvješća društva te o tomu sastaviti izvješće o reviziji koje se prilaže izvješću o primitcima (čl. 272.r st. 3. ZTD-a).

Društvo je obvezno objaviti i učiniti besplatno dostupnim na svojim mrežnim stranicama izvješće o primitcima i izvješće o reviziji na razdoblje od deset godina, nakon što glavna skupština odobri izvješće o primitcima ili ga raspravi (čl. 272.r st. 4. ZTD-a).

Člankom 43. ZID ZTD-a uvodi se novi članak 276.a ZTD-a koji predviđa pravo glavne skupštine glasovati o politici primitaka i izvješću o primitcima uvrštenih dioničkih društava. Njezine odluke o tim pitanjima imaju savjetodavnu narav. Glavna skupština najmanje jedanput u svake četiri godine odlučuje hoće li odobriti politiku primitaka za članove uprave, odnosno izvršne direktore koju joj je podnio nadzorni, odnosno upravni odbor, a uvijek kad se ona znatno izmijeni (čl. 276.a st. 1. ZTD-a). ${ }^{53}$ Odluka glavne skupštine i politika primitaka objavljuju se i čine besplatno dostupnim na mrežnim stranicama društva na razdoblje od barem deset godina, odmah nakon održane skupštine s naznakom datuma do kojeg će one vrijediti (čl. 276.a st. 2. ZTD-a). Ako skupština nije odobrila politiku primitaka, nadzorni, odnosno upravni odbor na prvoj sljedećoj skupštini podnijet će svoju izmijenjenu politiku primitaka, sukladno primjedbama prethodne skupštine te će se o njoj glasovati (čl. 276.a st. 3. ZTD-a).

Glavna skupština odlučuje hoće li odobriti izvješća o primitcima za prošlu poslovnu godinu koja su utvrđena i revidirana u skladu s čl. 272.r ZTD-a (čl. 276.a st. 4. ZTD-a). ${ }^{54}$ Ako je riječ o uvrštenim dioničkim društvima koja sukladno Zakonu o računovodstvu spadaju u mikro, male i srednje poduzetnike, ona nisu obvezna na donošenje odluke skupštine o odobrenju tog izvješća za proteklu poslovnu godinu, ako se o njemu raspravljalo na skupštini kao zasebnoj točki dnevnog reda (čl. 276.a st. 5. ZTD-a).

Članovima nadzornog, odnosno upravnog odbora (neizvršnim direktorima) može se za njihov rad platiti naknada koja se određuje statutom, a može ju svojom odlukom odobriti i glavna skupština društva. ${ }^{55}$ Upravna i nadzorna tijela te izvršni direktori o tomu ne mogu odlučivati. Ta naknada nije obvezatna za članove nadzornog, odnosno upravnog odbora, a svrha joj je nadoknaditi im troškove koji se javljaju u svezi s njihovim radom. Ona se može predvidjeti za sve članove nadzornih tijela ili samo za neke članove, pri čemu se oni ne smiju diskriminirati. ${ }^{56}$ Naknada mora biti primjerena poslovima koje obavlja član odbora i financijskom stanju društva. Ako je naknada određena statutom, glavna skupština može običnom većinom glasova donijeti odluku o izmjeni statuta kojom se ta naknada smanjuje (čl. 269. st. 1. ZTD-a). ${ }^{57}$

ZID ZTD u čl. 38. dopunjuje čl. 269. novim stavkom 3. kojim određuje da uvrštena dionička društva moraju najmanje svake četiri godine odlučivati o primitcima članova nadzornog, odnosno upravnog odbora. ${ }^{58}$ Dopuštena je odluka kojom se potvrđuje prijašnja odluka, a u njoj

Njezinom odlukom se ne preuzimaju obveze niti se stječu prava. 
se trebaju u razumljivu obliku navesti barem podatci o sustavu primitaka članova nadzornog, odnosno upravnog odbora. Ta odluka nije pobojna ako se prekrše pravila o podatcima koje treba sadržavati. Na donošenje i objavu odluke glavne skupštine o primitcima članova nadzornog, odnosno upravnog odbora na odgovarajući se način primjenjuju odredbe čl. 276.a st. 2. i 3. ZTD-a. Primitci članova tih tijela društva moraju se prikazati i u godišnjem izvješću o primitcima (čl. 272.r st. 1. ZTD-a).

\subsection{TRANSPARENTNOST I ODOBRENJE POSLOVA DRUŠTVA S POVEZANIM OSOBAMA}

Poslovi dioničkog društva s povezanim osobama mogu naštetiti društvu i njegovim dioničarima jer omogućuju povezanoj osobi prisvojiti vrijednost koja pripada društvu. Stoga treba osigurati da bitne poslove s povezanim osobama odobravaju dioničari ili nadzorni, odnosno upravni odbor društva, čime se štiti društvo i dioničari koji nisu povezana osoba, uključujući i manjinske dioničare. Te poslove valja javno objaviti najkasnije u trenutku njihova zaključivanja te navesti identitet povezane osobe, datum i vrijednost posla te druge informacije koje su potrebne za ocjenu primjerenosti tih poslova. ${ }^{59}$

ZID ZTD člankom 36. uvodi nove članke 263.a-263.d ZTD-a koji uređuju postupanje u slučaju sklapanja poslova između uvrštenog dioničkog društva i s njim povezanih osoba. Time se ograničava ovlast uprave, odnosno izvršnih direktora u vođenju poslova i zastupanju društva. Te odredbe nadopunjuju postojeće odredbe ZTD-a koje uređuju sukob interesa koji se može pojaviti između društva i članova uprave, odnosno izvršnih direktora te prokurista, kao i društva te članova nadzornog, odnosno upravnog odbora. ${ }^{60}$ Primjenjivat će se i odredbe ZTD-a o povezanim društvima.

Pod poslovima društva s povezanim osobama podrazumijevaju se pravni poslovi i radnje kojima se predmet ili neka druga imovinska vrijednost naplatno ili besplatno otuđuje, opterećuje ili prepušta i koji se poduzimaju s povezanim osobama. ${ }^{61} \mathrm{Za}$ određenje tko su povezane osobe upućuje se na primjenu Međunarodnih standarda financijskog izvješćivanja (čl. 263.a st. 1. ZTD-a). Tako Međunarodni računovodstveni standard 24 određuje tko se smatra povezanom osobom. ${ }^{62}$ To može biti fizička osoba ili član uže obitelji te osobe ${ }^{63}$ koja u društvu: a) ima kontrolu ili zajedničku kontrolu nad društvom (većinski dioničar) b) ima značajan utjecaj na društvo ili c) je član ključnog rukovodstva društva ili njegova društva majke (član uprave, izvršni direktor, prokurist, član nadzornog ili upravnog odbora). To može biti i pravna osoba povezana s društvom na neki od propisanih načina (npr. članstvo u istoj grupaciji društava,

59 Alineja 42.-44. Direktive (EU) 2017/828.

60 Zabrana konkurencije, obavještavanje društva o potencijalnom sukobu interesa, sklapanje ugovora sa samim sobom i sklapanje ugovora s članovima nadzornog tijela društva, primitci članova upravnih i nadzornih tijela društva i izvršnih direktora, davanje kredita članovima upravnih i nadzornih tijela društva, izvršnim direktorima, prokuristima i članovima njihovih užih obitelji.

61 Propuštanje nije posao društva s povezanom osobom.

62 Odluka o izmjenama i dopunama Odluke o objavljivanju međunarodnih standarda financijskog izvještavanja, Narodne novine, broj 120/2010.

63 Članovi uže obitelji neke osobe oni su članovi obitelji za koje se može očekivati da će utjecati na tu osobu ili biti pod njezinim utjecajem u poslovanju s društvom. 
odnos vladajućeg i ovisnog društva, mirovinski fond radnika društva, većinski dioničar, pravna osoba pod kontrolom fizičke osobe - većinskog dioničara društva i sl.).

U čl. 263.a st. 2. i 3. ZTD-a određuje se koji poslovi nisu poslovi društva s povezanim osobama te za njihovo sklapanje ne treba suglasnost nadzornog, odnosno upravnog odbora. To će biti sljedeći poslovi: a) redoviti poslovi društva koje ono poduzima s povezanim osobama pod uobičajenim tržišnim uvjetima ${ }^{64}$ b) poslovi s društvima kćerima, pod uvjetom da je društvo izravno ili neizravno njihov jedini član ili da u tim društvima kćerima ni jedna s društvom povezana osoba nema udio izravno ni neizravno c) poslovi s kojima se treba suglasiti ili ih odobriti glavna skupština d) svi poslovi i radnje koji se poduzimaju na temelju suglasnosti ili odobrenja glavne skupštine u skladu sa ZTD-om ${ }^{65}$ e) poslovi kojima se utvrđuju primitci članova uprave ili članova nadzornog odbora, odnosno izvršnih direktora i članova upravnog odbora u skladu sa ZTD-om f) poslovi koje sklopi kreditna institucija na temelju mjera kojima je cilj zaštita njezine stabilnosti i koje je donijelo ili odobrilo nadležno tijelo zaduženo za bonitetni nadzor u smislu prava EU-a te g) poslovi koji se nude svim dioničarima pod jednakim uvjetima.

Nadzorni, odnosno upravni odbor uvrštenog dioničkog društva treba dati prethodnu suglasnost za poslove koje društvo poduzima s povezanim osobama ako oni premašuju propisanu vrijednost (čl. 263.b st. 1 . ZTD-a). ${ }^{66}$ Članu toga odbora isključeno je pravo glasa kad se glasuje o davanju suglasnosti ako je on ujedno i povezana osoba s kojom društvo poduzima posao (čl. 263.b st. 2. ZTD-a). Ako nadzorni, odnosno upravni odbor uskrati prethodnu suglasnost za taj posao, uprava, odnosno izvršni direktori mogu zahtijevati da odluku o tomu donese glavna skupština. Dioničaru je isključeno pravo glasa kad se glasuje o toj odluci ako je on ujedno i povezana osoba s kojom društvo poduzima posao (čl. 263.b st. 4. ZTD-a).

Poslovi društva s povezanim osobama za koje je potrebna prethodna suglasnost nadzornog, odnosno upravnog odbora moraju se bez odgode objaviti na mrežnim stranicama društva ili na drugi način koji omogućava javnosti dostupnost obavijesti. Obavijest na mrežnim stranicama društva mora biti dostupna javnosti najmanje pet godina od dana objave (čl. 263.d st. 1. ZTD-a). ${ }^{67}$ Ona mora sadržavati sve bitne informacije koje su potrebne za ocjenu je li posao primjeren sa stajališta društva i dioničara koji nisu povezane osobe (čl. 263.d st. 2. ZTD-a). ${ }^{68}$

64 Uvrštena dionička društva trebaju provoditi unutarnji postupak radi redovite provjere je li društvo poslovalo s povezanim osobama u skladu s uobičajenim tržišnim uvjetima. U tim provjerama ne smiju sudjelovati povezane osobe. Statutom se može odrediti da će se za sklapanje tih poslova s povezanim osobama tražiti suglasnost nadzornog, odnosno upravnog odbora.

65 To će osobito biti: a) radnje povezane s povećanjem ili smanjenjem temeljnog kapitala, poduzetničkim ugovorima te poslovi koji se poduzimaju na temelju tih ugovora b) prijenos cijele imovine društva, odnosno strukturne promjene c) stjecanje vlastitih dionica na temelju odluke glavne skupštine d) ugovori na koje se primjenjuju pravila o nastavku osnivanja društva e) prijenos dionica manjinskih dioničara na glavnog dioničara te f) poslove u okviru statusnih promjena društva.

66 Vrijednost posla mora samostalno ili zajedno s drugim poslovima koje je društvo poduzelo s povezanom osobom u posljednjih dvanaest mjeseci prije nego što se taj posao poduzima premašivati $2,5 \%$ zbroja dugotrajne i kratkoročne imovine utvrđene posljednjim godišnjim financijskim izvješćima. Dugotrajna i kratkoročna imovina određuju se u skladu s propisima o računovodstvu koji su na snazi u vrijeme primjene. Ako je društvo kao vladajuće društvo dužno utvrditi konsolidirano godišnje financijsko izvješće u skladu sa ZTD-om, treba uzeti zbroj dugotrajne i kratkoročne imovine koncerna utvrđen posljednjim konsolidiranim godišnjim financijskim izvješćima vladajućeg društva koncerna (čl. 263.b st. 3. ZTD-a).

67 Objava se odnosi i na poslove koje treba, zajedno s poslom za koji je potrebna prethodna suglasnost, uzeti u obzir pri izračunu vrijednosti posla s povezanom osobom.

$68 \mathrm{U}$ obavijesti se moraju barem navesti informacije o prirodi odnosa s povezanom osobom, njezinu identitetu te datumu i vrijednosti posla. Obveza objave neće postojati ako je informacija već objavljena u skladu s čl. 17. Uredbe (EU) br. 596/2014 o zlouporabi tržišta (čl. 263.d st. 3. ZTD-a). 
Članak 37. ZID ZTD-a mijenja čl. 264. st. 3. ZTD-a te određuje da nadzorni, odnosno upravni odbor može imenovati i komisiju koja će predlagati odluke o davanju prethodne suglasnosti za poslove društva s povezanim osobama. ${ }^{69}$ Ako ta komisija predloži nadzornom, odnosno upravnom odboru uskratu prethodne suglasnosti poslu koji društvo namjerava poduzeti s povezanom osobom, taj se odbor smije suglasiti s poslom samo ako revizor ili revizijsko društvo potvrdi da je posao društva i povezane osobe primjeren sa stajališta društva i dioničara koji nisu povezane osobe (čl. 263.c st. 1. ZTD-a). Ako nadzorni, odnosno upravni odbor nema te komisije, pri glasovanju o prethodnoj suglasnosti isključuje se pravo glasa onim njegovim članovima glede kojih postoji sumnja da su u sukobu interesa na temelju njihovih odnosa $s$ povezanim osobama (čl. 263.c st. 2. ZTD-a).

\section{ZAKLJUČAK}

Izmjenama i dopunama ZTD-a iz 2019. godine implementiraju se u hrvatsko pravo odredbe Direktive (EU) 2017/828 s ciljem poticanja dioničara sudjelovati u radu glavnih skupština društava čije su dionice uvrštene na uređeno tržište radi trgovanja. To se osobito odnosi na slučajeve kada prava iz dionica za dioničare ostvaruju posrednici koji pohranjuju i ostvaruju prava iz vrijednosnih papira svojih klijenata. Uspostavlja se obveza društva obavještavati dioničare izravno ili preko posrednika o sazivanju glavne skupštine i određenim korporativnim događajima. Društvo ima pravo tražiti informacije o identitetu dioničara od posrednika, a dioničari odlučuju hoće li svoja prava na skupštini ostvarivati osobno ili preko posrednika. Ako se pravo glasa na skupštini ostvaruje elektroničkom komunikacijom, društvo mora osobi koja je glasovala dati elektroničku potvrdu o primitku glasa, kao i potvrdu o glasovanju nakon održavanja skupštine. Te će se odredbe ZTD-a primjenjivati od 1. siječnja 2021. godine.

S obzirom na brojnost i značaj institucionalnih ulagača, upravitelja imovinom i savjetnika pri glasovanju, uvode se zahtjevi za transparentnost njihovih politika sudjelovanja, dogovora i pružanja usluga krajnjim korisnicima. Time se osigurava bolja obaviještenost i nadzor krajnjih korisnika postupaju li u skladu s njihovim interesima pri ulaganju u uvrštena dionička društva.

Kada je riječ o primitcima članova upravnih i nadzornih tijela te izvršnih direktora uvrštenih dioničkih društava, propisuje se obveza izrade politike primitaka te godišnjeg izvješća o primitcima. Glavna skupština mora odobriti politiku primitaka te godišnje izvješće o primitcima, pri čemu su te odluke savjetodavne naravi. Politika primitaka i godišnje izvješće o primitcima moraju se objaviti na mrežnim stranicama društva. Ove će se odredbe ZTD-a primjenjivati od 1. svibnja 2020. godine.

Poslove uvrštenog dioničkog društva s povezanim osobama, a koji premašuju propisanu vrijednost, moraju prethodno odobriti nadzorni, odnosno upravni odbori te se oni objavljuju na mrežnim stranicama društva. Time se štiti imovina društva te interesi manjinskih dioničara.

69 Većina članova te komisije ne smiju biti povezane osobe koje sudjeluju u poslu, a nadzorni, odnosno upravni odbor treba za njih procijeniti postoji li sumnja da su u sukobu interesa na temelju njihovih odnosa s povezanim osobama. 


\section{LITERATURA}

1. Barbić, J., Pravo društava, Knjiga druga - društva kapitala, Svezak I.: dioničko društvo, Organizator, Zagreb, 2010.

2. Belanić, L.; Bilić, A.; Gorenc, V.; Kunštek, E.; Markovinović, H.; Mihalina, E.; Mihelčić, G.; Miladin, P.; Mišćenić, E.; Perkušić, M.; Petrić, S.; Slakoper, Z.; Šrajfer, J.; Tepeš, N.; Tot, I.; Vukmir, B., Bankovni i financijski ugovori, Narodne novine, Zagreb, 2017.

3. Čulinović-Herc, E.; Hasić, T., Sudjelovanje dioničara u radu glavne skupštine dioničkog društva prema noveli Zakona o trgovačkim društvima, Zbornik Pravnog fakulteta Sveučilišta u Rijeci, god. 32, br. 1, 2011., str. 31.-73.

4. Čulinović-Herc, E.; Jurić, D., Prekogranični aspekti prava glasa - otvorena pitanja u europskom i hrvatskom pravu, Prekogranična i regionalna suradnja - zbornik radova s međunarodnog znanstvenog skupa, Pravni fakultet Sveučilišta u Rijeci, Rijeka, 2007., str. 219.-248.

5. Jurić, D., Primanja za rad i objavljivanje podataka o primanjima za rad članova uprave i nadzornog odbora dioničkog društva, Financiranje, upravljanje i restrukturiranje trgovačkih društava u doba recesije, Pravni fakultet Sveučilišta u Rijeci, Rijeka, 2011., str. 115.-156.

6. Kocbek, M., Revizija direktive o pravicah delničarjev - Direktiva (EU) 2017/828 Evropskega parlamenta in Sveta z dne 17 maja 2017 o spremembi Direktive 2007/36/ES glede spodbujanja dolgoročnega sodelovanja delničarjev, Podjetje in delo, god. XLIV, br. 2, 2018., str. 361.-373.

7. Markovinović, H.; Tepeš, N., Ostvarivanje prava glasa po dionicama u skrbništvu, Financiranje, upravljanje i restrukturiranje trgovačkih društava u doba recesije, Pravni fakultet Sveučilišta u Rijeci, Rijeka, 2011., str. 339.-377.

\section{POPIS PROPISA, AKATA I SUDSKIH ODLUKA}

1. Direktiva (EU) 2017/828 Europskog parlamenta i Vijeća od 17. svibnja 2017. godine o izmjeni Direktive 2007/36/EZ u pogledu poticanja dugoročnog sudjelovanja dioničara (tekst značajan za EGP), Službeni list EU, L 132/1 (20. svibnja 2017.).

2. Odluka o izmjenama i dopunama Odluke o objavljivanju međunarodnih standarda financijskog izvještavanja, Narodne novine, broj 120/2010.

3. Provedbena uredba Komisije (EU) 2018/1212 od 3. rujna 2018. o utvrđivanju minimalnih zahtjeva za provedbu odredbi Direktive 2007/36/EZ Europskog parlamenta i Vijeća u pogledu utvrđivanja identiteta dioničara, prijenosa informacija i olakšavanja ostvarivanja prava dioničara, Službeni list EU, L 223/1 (4. rujna 2018.).

4. Zakon o trgovačkim društvima, Narodne novine, broj 111/1993, 34/1999, 121/1999, 52/2000, 118/2003, 107/2007, 146/2008, 137/2009, 125/2011, 152/2011, 111/2012, 68/2013, 110/2015.

5. Zakon o tržištu kapitala, Narodne novine, broj 65/2018.

6. Zakon o izmjenama i dopunama Zakona o trgovačkim društvima, Narodne novine, broj 40/2019. 


\section{MREŽNI IZVORI}

1. Vlada RH, Konačni prijedlog zakona o izmjenama i dopunama Zakona o trgovačkim društvima, Zagreb, travanj 2019. https://sabor.hr/sites/default/files/uploads/sabor/2019-04-04/164502/PZE-599. pdf. Pristupljeno 9. travnja 2019.

2. European Commission, Commission staff working document: impact assessment accompanying the document Proposal for a Directive of the European Parliament and of the Council on amending Directive 2007/36/EC as regards the encouragement of long-term shareholder engagement and Directive 2013/34/ $E U$ as regards certain elements of the corporate governance statement and Commission Recommendation on the quality of corporate governance reporting ('comply or explain'), SWD(2014) 127 final, Bruxelless, travanj 2014. https://eur-lex.europa.eu/legal-content/EN/TXT/?uri=CELEX:52014SC0127. Pristupljeno 29. svibnja 2019. 


\section{DIRECTIVE (EU) 2017/828 AMENDING DIRECTIVE 2007/36/EC AS REGARDS THE ENCOURAGEMENT OF LONG-TERM SHAREHOLDER ENGAGEMENT AND ITS IMPLEMENTATION IN CROATIAN COMPANY \\ LAW}

\section{Summary}

In April 2019 the Croatian Companies Act was amended and harmonized with provisions of the Directive (EU) 2017/828 amending Directive 2007/36/EC as regards the encouragement of long-term shareholder engagement. These amendments introduce new regulatory requirements for listed companies with aim to encourage shareholders to exercise their rights on general meetings, especially when their shares are held by intermediaries. Institutional investors, asset managers and proxy advisors must publicly disclose information about their investment strategies, their engagement policy and the implementation thereof. Shareholders are included in establishment of the remuneration policy for directors of listed companies and adoption of the annual remuneration report. Related party transactions must be approved by the administrative or supervisory body of the listed company and they must be publicly announced on the website of the company.

Keywords: $\quad$ Directive (EU) 2017/828, Companies Act, listed companies, corporate governance, Republic of Croatia

\section{(c) (1) (8)}

This work is licensed under a Creative Commons

Attribution-NonCommercial 4.0 International License.

* Dionis Jurić, PhD, Full Professor, Faculty of Law, University of Rijeka, Hahlić 6, 51000 Rijeka, Republic of Croatia. Email address: djuric@pravri.hr. ORCID: http://orcid.org/0000-0001-7725-7531. 